JOURNAL OF AGRICULTURE AND APPLIED BIOLOGY

2020, Vol. 1, No. 2, $100-117$

http://dx.doi.org/10.11594/jaab.01.02.08

Review Article

\title{
Use of neem (Azadirachta indica A. Juss) as a biopesticide in agriculture: A review
}

\author{
Kripa Adhikari ${ }^{*}$, Sudip Bhandari ${ }^{1}$, Dikshya Niraula $^{1}$ and Jiban Shrestha ${ }^{2}$ \\ ${ }^{1}$ Tribhuvan University, Institute of Agriculture and Animal Science, Prithu Technical College, \\ Deukhuri, Dang, Nepal \\ ${ }^{2}$ Nepal Agricultural Research Council, National Plant Breeding and Genetics Research Centre, \\ Khumaltar, Lalitpur, Nepal
}

Article history:

Submitted 21 November 2020

Accepted 12 December 2020

Published 28 December 2020

Keywords:

Azadirachtin

Pesticide

Insect

Pest

*Corresponding author:

E-mail:

kripaadhikary9@gmail.com

\begin{abstract}
Neem (Azadirachta indica A. Juss) is a member of Meliaceae family, a fast-growing tropical evergreen plant whose products were found effective against economically important insect pests and diseases. All parts of this plant particularly leaf, bark, and root extracts have the biopesticidal activities. Azadirachtin, a biopesticide obtained from neem extract, can be used for controlling various insect pests in agriculture. It acts on insects by repelling them, by inhibiting feeding, and by disrupting their growth, and reproduction. Neem-based formulations do not usually kill insects directly, but they can alter their behavior in significant ways to reduce pest damage to crops and reduce their reproductive potential. The neem is considered as an easily accessible, eco-friendly, biodegradable, cheap, and nontoxic biopesticide which control the target pests. Thus, this review highlighted the extract, byproducts and roles of neem that can be used as potential biopesticide in agriculture.
\end{abstract}

\section{Introduction}

Pesticides are the chemical substances that are used to decimate, repulse, prevent, and control the pests creating nuisances and help to increase the yield in agricultural sector (Kumar et al., 2012). The increasing population has exaggerated the use of synthetic pesticides to fulfill their demand for food which have been proven hazardous to biotic and abiotic factors (Macintosh, 2017). The report presented by World Health Organization (WHO) and United Nation Environment Programme UNEP clarifies that pesticides are responsible for poisoning around three million people and causing around 200,000 deaths each year, worldwide, more cases $(95 \%)$ being reported in developing countries (World Health Organization, 1990; Yadav et al., 2015). The attractive veggies in the markets are grown with the heavy use of chemical pesticides. The risk associated with excessive usage of chemical pesticide had caused unpredicted environmental issues, insecticide resistance, pest resurgence, and health hazards on the plant and soil that are recognized as an ecologically unacceptable activity (Damalas \& Eleftherohorinos, 2011). 
These days all the concern has been provided towards the organic, safe, and non-toxic pesticides that could replace the synthetic ones (Acharya et al., 2017). Biopesticides are the alternative way to the synthetic pesticides and naturally derived preparations or formulations that control pests by non-toxic mechanisms in an eco-friendly manner (Gupta \& Dikshit, 2010). They are educed from plants, animals, microbes, safe, and safe to the environment (Mazidet et al., 2011). Biopesticide circumscribes multiple pest control strategies, plantdeduced pesticides (botanicals), microbial (viral, bacterial or fungal), entomophagous nematodes, secondary metabolites from microbes (antibiotics), insect pheromones used for mating disruption and genetical modification to express resistances to various pest attacks (Copping \& Menn, 2000). Among various biopesticides, neem (Azadirachta indica) has emerged as a highly reliable source of biopesticides (Raizada et al., 2001). It is on the top list among 2400 botanicals used as biopesticide worldwide.

Neem (Azadirachta indica) is highly exploited recognized as "Life giving tree", "Village pharmacy", "Divine tree", "sacred offering of nature" with having several valuable properties (Hossain \& Nagooru, 2011; Kumar \& Navartnam, 2013). It is such an amazing plant which has been declared the "Tree of the $21^{\text {st }}$ century" by the United Nations (UNEP, 2012). The Neem or Margosa tree may attain a height of $30 \mathrm{~m}$ and have a girth of $2.5 \mathrm{~m}$ (Rangiah \& Gowda, 2019). Neem can tolerate intense drought, poor soil, and even shallow soils because of its deep root system and can thrive in a sub-humid to sub-arid climate with an annual rainfall of 400-800 mm (Schmutterer, 1990). Each part of the neem plant like seeds, leaves, roots, barks, and flower are known to have fungicidal, insecticidal, and nematicidal properties (Bajwa \& Ahmad, 2012). Among all, leaves and seed extract of neem have been most widely used because of their deleterious effects on insect pests (Nathan et al., 2008). The leaves of $A$. indica contains carbohydrates (48-58\%), protein (14-18\%), crude fibre (11-24\%), ash (7.7$8.5 \%)$, crude fat $(2.3-6.9 \%)$, calcium $(0.8-2.4 \%)$ and phosphorus (0.13-0.24\%), numerous of amino acids, as well as carotenoids and other constituents (Debashri \& Tamal, 2012). Neem oil cake contains high amount of Sulphur and neem oil is rich in fatty acid (Schmuttere, 2002). Sugars and polysaccharides have also been identified and isolated from the gum and bark of $A$. indica (Fulekar, 2005). The biologically active compounds present on Neem are over and above 100 compounds (Benelli et al., 2015) to the total of 300 compounds found till now (Gosse et al., 2005). In an experiment conducted by Tripathi et al. (2020), Neem was used as botanical pesticide in controlling insect pest of cucurbits in Lamjung district of Nepal.

Various biochemical products like Nimbolide, Margolone, Mahoodin, Margolonone, etc. More than of exceeding 60 biochemical products been purified from neem (Krishnaiah et al., 2007; Olabinri et al., 2013). There are about more than 540 species of major pests which are considered vulnerable to the agricultural crops belonging to the different orders of insects. These orders include: Diptera, Hymenoptera, Coleoptera, Lepidoptera, Orthoptera, and Hemiptera (Schmuttere et al., 2002; Khan et al., 2015).

The benefits of neem stated by Salako (2002) such as: i) It is readily available and is relatively cheap; ii) The active compounds of neem have brought a remarkable change in the different stages of insect's life cycle and physiology making harder for pests to survive and resist; iii) The action of neem is systemic due to which plant protection is the foremost role played by it and has been protecting rice, maize, wheat, barley, sugarcane, tomatoes, cotton, brinjal and other various crops, and vegetables for up to 10 weeks against the harmful pests; iv) The large spectrum of insects are being controlled by Neem which includes even a lice in human to armyworms, Locusta migatoria, pathogens like Meloidogyne root-knot nematode, rhizoctonia root-rot fungus, and Rice stunt virus in the fields (Anjorin et al., 2004); v) It has no harmful effects to those organisms which seem to be beneficial in the field. eg: earthworm.

This review paper outlined the current state of knowledge on the potential uses of neem as a biopesticide in control of insect pests in agriculture. 


\section{Major neem products}

The major neem extract such as neem oil, leaf extracts, bark extracts, and root extracts as well as the by-product of neem i.e., neem cake contain pesticidal properties and are used as bio-pesticide, fungicide and organic manure (Acharya et al., 2017). These extracts and byproducts can be used singly or can be mixed with the other compounds to produce the final products (Sara et al., 2004). These products have the properties of antifungal, antibacterial, antiviral, antidiabetic, anthelmintic, anti-carcinogenic, antiinflamatory, used as contraceptive and sedative (Acharya et al., 2017)

\section{Neem oil}

Neem oil, the most important extract of neem tree, is widely used worldwide for pest control activities (Benelli \& Pavela, 2018). Neem oil is a better pesticide due to its repellent, insecticidal, nematicidal, bactericidal, and fungicidal activities (Pascoli et al., 2019). The oil contains around 300 biologically active compounds, most notably azadiractin - a triterpene (Chandramohan et al., 2016; Gupta et al., 2017). The existence of terpenoid, limonoids, and volatile sulphur containing compounds makes Azadirachtin oil as a complex oil (Ricci et al., 2009). The oil obtained from the seed contains volatile oil and fatty acids in abundant amount (Djenontin et al., 2012) whereas the oil obtained from flower and leaves have lesser number of volatile oils $(0.08 \%)$, and these consists of about $85 \%$ of caryophyllene. The oil obtained from seed has been reported to have larvicidal activity on mosquitoes (Dua et al., 2009). It has been proved that the Neem oil as an effective insecticide against various pests like Scirpophaga incertulas (Madhu et al., 2020), Nilaparvata lugens (Senthil-Nathan et al., 2009), Cnaphalocrocis medinalis (Nathan et al., 2006), Spodoptera frugiperda (Tavares et al. 2010), Helicoverpa armigera (Ahmad et al., 2015), Idioscopus clypealis (Adnan et al. 2014), Diaphorina citri (Weathersbee \& McKenzie, 2005). Similarly, the spray of two neem formulations neem seed oil, and azadirachtin were effective in causing the nymphal mortality of Aphis glycines $(80 \%$ by azadirachtin and $77 \%$ by neem oil) (Kraiss \& Cullen, 2008). Use of neem oil causes lethal toxicity to the pupal stage of insects which leads to several morphological deformations such as malformed adults, partial ecdysis, and molt blocking, that defers and inhibits adult formation (Boulahbel et al., 2015).

\section{Neem seed cake}

Neem seed cake is the residue obtained after extracting the oil from seed kernels and can be used as biopesticide as well as biofertilizer (Chaudhary et al., 2017). It acts as a soil enricher, provides nutrients necessary for all plant growth, deters on activity of soil pest and bacteria and helps to increase the yield of plants (Roshan \& Verma, 2015). Neem cake not only provides organic amendment to the soil but also reduces the loss of nitrogen in the field providing the essential nutrient and acts as a biofertilizer for effective growth and development of the plant (Ramachandran et al., 2007; Lokanadhan et al., 2012). The chemical composition of cake include Azadirachtin, Nitrogen (3.56\%), phosphorous $(0.83 \%)$, potassium $(1.67 \%)$, calcium $(0.99 \%)$, and magnesium (0.75\%) (Rangiah \& Godwa, 2019). Several 50 $\mathrm{kg}$ ripe fruits of neem having $30 \mathrm{~kg}$ of seeds kernels provide $24 \mathrm{~kg}$ of seed cake. The use of neem cake @ $200 \mathrm{~g} \mathrm{~m}^{-2}$ with arbuscular mychorrhiza fungus was effective on increasing the plant height in okra, increased the phosphorous content in the field and was effective in controlling the root knot nematode in okra (Mohapatra et al., 2020). Similarly, Neem cake @ $1 \mathrm{~kg}$ per vine is reported to be efficient against nematode of black pepper (Sathyan et al., 2020). However, it is recommended to use neem cake @ 3 t ha $^{-1}$ along with the use of FYM in the field of spice crops like turmeric, ginger, and large cardamom for increasing productivity (Das et al., 2018). The application of neem cake @ $150 \mathrm{~kg} \mathrm{ha}^{-1}$ is effective for the management of soil borne pests in the staple crops like rice and maize. Neem cake when applied to the field is regarded as the best nutrient management option in the crops like rice, maize, buckwheat, mustard, rapeseed, soybean, ginger, and turmeric (Das et al., 2020). Neem cake was found to be more effective than the leaf extracts 
in case of detering fall army worm (Spodoptera frugiperda) (Silva et al., 2015).

\section{Neem leaves}

The biologically active compound present on the neem leaves are alkaloids, glycosides, tannins, flavinoids, reducing sugars, carbohhydrates, and steroids (Manikandan et al., 2008). Neem leaves extract are the excellent source for the preparation of vermi-compost which increase soil fertility and also have pesticidal properties (Chaudhary et al., 2017). Neem leaves accelerates the growth and reproduction in earthworm when added while vermicomposting (Gajalakshmi \& Abbasi, 2004). Use of neem leaves protects stored grain by repelling the stored grain pests and increasing the post-harvest life (Ahmad et al., 2015). Neem leaf powder @10 g concentration was found to be effective on the stored rice weevil (Jahan et al., 2019).

Crude water extracts of green neem leaves @ $200 \mathrm{~g}$ of leaves per liter of water can be effective for controlling cabbage butterfly, soybean hairy caterpillar and tobacco caterpillar (Parajuli et al., 2020). Bhatta et al. (2019) conducted an experiment in Lamjung, Nepal and found that the plant aqueous extracts of Neem (Azadiracta indica) reduced the aphid population in Tori. Neem leaves are used in different forms either grinded and made into powdered form or with aqueous, methanolic or ethanolic extracts (Kumar et al., 2019). In recent study, the ethanolic extracts of neem leaves-based seaweed films enhanced the anti-microbial activity which made a sustainable packaging material (Kumar et al., 2019). Similarly, the effect of neem leaves extracts showed the inhibition of biofilm of Pseudomonas aeruginosa (Kaverimanian et al., 2020). Leaf extracts are found to be effective on bean aphid (Bahar et al., 2007) and it also reduced population of whitefly and aphid on cabbage (Basedow et al., 2002; Zaki, 2008). The leaf extracts when mixed with the garlic bulb were efficient to reduce aphids, whiteflies destructing several crops (Pareet, 2006).

\section{Neem bark}

The use of neem barks extracts as biopesticide are not as popular as the seeds and leaves, that have been used in an extensive way (Sirohi \& Tandon, 2014). It is found that the bark extracts when applied to the field acts as phytotoxic materials and showed germination and growth inhibitor on rice, radish, carrot, sesame, and bean demonstrating allelopathic properties (Xuan et al., 2004). Neem bark extract dyed fabric was more significant than the leaf extracts due to the presence of higher azadirachtin, cyanogenic glucosides, and nimbin content and exhibited anti-lepidopteran efficacy (Ahmad et al., 2015). A nano formulation made to the concentration of $100 \mathrm{ppm}$ from the crude neem gum, collected from the neem bark, showed $100 \%$ mortality against the larva, pupa of Helicoverpa armigera and Spodoptera litura in the field and reported the antifeedant activities on them (Kamaraj et al., 2017).

\section{Neem roots}

Neem root extracts can be used either as raw or in the powdered form or by extracting it soil. The roots of neem tree have anti-bacterial, anti-fungal, anti-septic properties (Lokanadhan et al., 2012). Endophytic fungal flora can also be isolated from the roots of the neem tree (Verma et al., 2011). Nowdays, 361 fungi and 80 bacterial endophytes have been isolated from different parts including root and these endophytes reduced the environmental microrganisms (Rangiah \& Gowda, 2019). Extracts of root are used against the sucking insects and fleas (Lokanadhan et al., 2012).

The effectiveness of various neem pesticides on reducing the damage of various insect pests in major cereal crops is given in Table 1 . 
Table 1. The effectiveness of neem pesticides against various food crops pests

\begin{tabular}{|c|c|c|c|c|}
\hline SN. & Crops & Products used & Pests & References \\
\hline \multirow[t]{3}{*}{1.} & \multirow[t]{3}{*}{ Rice } & $\begin{array}{l}\text { Handi Ausadha pot mixture } \\
\text { (5:l fermeted cow urine+ } 1 \\
\mathrm{~kg} \text { fresh cow dung+ } 1 \mathrm{~kg} \\
\text { karanj leaves+ } 1 \mathrm{~kg} \text { neem } \\
\text { leaves+ } 1 \mathrm{~kg} \text { calotropis } \\
\text { leaves and } 50 \mathrm{~g} \text { Gaur @ } \\
20 \mathrm{~mL} \mathrm{~L}^{-1} \text { ) }\end{array}$ & $\begin{array}{l}\text { Reduce the incidence of pest } \\
\text { by yellow stem borer } \\
(73.13 \%) \text {, Green leaf hopper } \\
(75.12 \%) \text {, Gall midge } \\
(69.93 \%) \text {, Dead heart and } \\
\text { white ear head ( } 69.26 \%) \text {, } \\
\text { thrips }(79.73 \%) \text {, and leaf } \\
\text { folder }(85.57 \%) .\end{array}$ & $\begin{array}{l}\text { (Mohapatra, } \\
\text { 2018) }\end{array}$ \\
\hline & & $\begin{array}{l}\text { Multineem 300ppm @ 2.5 L } \\
\text { ha }^{-1}\end{array}$ & $\begin{array}{l}\text { Brown plant hopper, Yellow } \\
\text { Stem borer (Scirpophaga in- } \\
\text { certulas) }\end{array}$ & $\begin{array}{l}\text { (Dash et al., } \\
\text { 2019) }\end{array}$ \\
\hline & & $\begin{array}{l}\text { Nimbecidine @ } 5 \mathrm{~mL} \mathrm{~L}^{-1} \mathrm{~W} \text {, } \\
5 \mathrm{~mL} \mathrm{~L}^{-1} \text { of Neem oil }\end{array}$ & $\begin{array}{l}\text { Brown plant hopper } \\
\text { (Nilaparvata lugens) }\end{array}$ & $\begin{array}{l}\text { (Choudhary et } \\
\text { al., 2017) }\end{array}$ \\
\hline \multirow[t]{4}{*}{2.} & \multirow[t]{4}{*}{ Maize } & Local Neem & Sitophilus zeamais, & $\begin{array}{l}\text { (Khanal et al., } \\
\text { 2019) }\end{array}$ \\
\hline & & $\begin{array}{l}\text { Aqueous Neem extract } \\
@ 300 \mathrm{~L} \mathrm{ha}^{-1}\end{array}$ & $\begin{array}{l}\text { Corn ear worm (Heliothis } \\
\text { armigera) }\end{array}$ & $\begin{array}{l}\text { (Udo \& Ibanga, } \\
\text { 2019) }\end{array}$ \\
\hline & & $\begin{array}{l}\text { Neem leaf extract @ } 2 \mathrm{~mL} \\
\mathrm{~L}^{-1}\end{array}$ & $\begin{array}{l}\text { Maize aphid (Rhoph- } \\
\text { alosiphum maidis) }\end{array}$ & $\begin{array}{l}\text { (Alam et al., } \\
\text { 2019) }\end{array}$ \\
\hline & & Neem oil and seed cake & $\begin{array}{l}\text { Fallarmyworm (Spodoptera } \\
\text { furgiperda) }\end{array}$ & $\begin{array}{l}\text { (Shaiba et al., } \\
\text { 2019) }\end{array}$ \\
\hline \multirow[b]{2}{*}{3.} & \multirow[b]{2}{*}{ Wheat } & Neem Seed Kernel Extract & $\begin{array}{l}\text { Wheat aphid (Raphalosi } \\
\text { phumpadi) }\end{array}$ & $\begin{array}{l}\text { (Matharu \& } \\
\text { Tanwar, 2019) }\end{array}$ \\
\hline & & $\begin{array}{l}\text { (Indoneem) 1500ppm @ } \\
1200 \mathrm{~mL} \mathrm{ha}^{-1} \\
3 \% \text { Neem oil and neem } \\
\text { seed }\end{array}$ & $\begin{array}{l}\text { Wheat aphid (Raphalosi } \\
\text { phumpadi) }\end{array}$ & $\begin{array}{l}\text { (Bushra et al., } \\
\text { 2014) }\end{array}$ \\
\hline
\end{tabular}


The various neem products and their targets to control insect pests in horticultural crops is given in Table 2.

Table 2. The various neem products for the control of insect pests in horticultural crops

\begin{tabular}{|c|c|c|c|c|}
\hline S.N. & Crops & Products used & Pests & References \\
\hline 1. & Cabbage & $3 \%$ concentration of Neem & Plutella xylostella & $\begin{array}{l}\text { (Ahmad et al., } \\
\text { 2019) }\end{array}$ \\
\hline 2. & $\begin{array}{l}\text { Cauli- } \\
\text { flower }\end{array}$ & $\begin{array}{l}\text { Neem oil }(58.26 \% \text { and } \\
57.89 \%), \text { neem seed kernel } \\
\text { extract }(54.83 \% \text { and } \\
55.24 \%), \text { neem leaf extract } \\
(50.70 \% \text { and } 51.42 \%)\end{array}$ & Spodoptera litura & (Singh et al., 2019) \\
\hline 3. & Egg Plant & Neem oil & Leucinodes arbonalis & $\begin{array}{l}\text { (Rakibuzzaman et } \\
\text { al., 2019) }\end{array}$ \\
\hline \multirow[t]{2}{*}{4.} & \multirow[t]{2}{*}{ Potato } & $\begin{array}{l}\text { Neem oil and karanja oil in } \\
\text { ratio of } 1: 1,1.4 \mathrm{~L} \text { in } 500 \mathrm{~L} \\
\text { water } \text { ha }^{-1}(0.3 \%) .\end{array}$ & $\begin{array}{l}\text { Colorado potato bee- } \\
\text { tle }\end{array}$ & $\begin{array}{l}\text { (Kovaříková \& } \\
\text { Pavela 2019) }\end{array}$ \\
\hline & & Neem oil 300ppm & $\begin{array}{l}\text { Green peach aphid } \\
\text { (Myzus persicae) }\end{array}$ & $\begin{array}{l}\text { (El-Wahab et al., } \\
\text { 2019) }\end{array}$ \\
\hline \multirow[t]{3}{*}{5.} & \multirow[t]{3}{*}{ Tomato } & $\begin{array}{l}\text { Neem cake, leaves, and re- } \\
\text { fined product "aza" } 0.1 \% \\
\text { w/w }\end{array}$ & Root knot Nematode & (Javed et al., 2007) \\
\hline & & $\begin{array}{l}\text { Nursery bed treatment } 3 \mathrm{~kg} \\
\mathrm{~m}^{-2}\end{array}$ & Root not nematode & $\begin{array}{l}\text { (Illakwahhi \& Sri- } \\
\text { vastava, 2019) }\end{array}$ \\
\hline & & $\begin{array}{l}\text { Neem oil: Abamectin @ } \\
\text { 100ppm 1:1 ratio }\end{array}$ & $\begin{array}{l}\text { Tomato leaf miner } \\
\text { (Tuta absoluta) }\end{array}$ & (Javed et al., 2007) \\
\hline \multirow[t]{3}{*}{6.} & \multirow[t]{3}{*}{ Okra } & $2 \%$ Neem seed extract & Jassid, White fly & $\begin{array}{l}\text { (Aziz \& Khoso, } \\
\text { 2019) }\end{array}$ \\
\hline & & Neem seed kernel extract $5 \%$ & $\begin{array}{l}\text { white fly, Jassid and } \\
\text { Fruit borer }\end{array}$ & (Ketkar, 2000) \\
\hline & & $\begin{array}{l}\text { Soaking Okra seeds for } 20-30 \\
\text { minutes in } 5 \% \text { aqueous solu- } \\
\text { tion of neem cake against } \\
\text { root-knot nematode. }\end{array}$ & Root-knot nematode & (Ketkar, 2000) \\
\hline 7. & Pumpkin & Neem seed kernel extract $5 \%$ & Red pumpkin beetle & (Ketkar, 2000) \\
\hline 8. & Cucumber & Neem extract & $\begin{array}{l}\text { Two spotted spider } \\
\text { mite (Tetranychus } \\
\text { urticae Koch), Aphis } \\
\text { gossypii Glov. }\end{array}$ & $\begin{array}{l}\text { (Saleem et al., } \\
\text { 2019) }\end{array}$ \\
\hline 9. & Ginger & $\begin{array}{l}\text { Neem leaf powder @ } 500 \mathrm{~g} \\
\mathrm{~m}^{-2}\end{array}$ & Rhizome rot & (Ketkar, 2000) \\
\hline 10. & Coriander & $\begin{array}{l}\text { Kernel (5\%), neem cake } \\
(5 \%), \text { neem oil }(3 \%) \text { and } \\
\text { neem leaf extract }(5 \%)\end{array}$ & $\begin{array}{l}\text { Coriander aphid (Hy- } \\
\text { adaphis coriandari) }\end{array}$ & $\begin{array}{l}\text { (Kumari \& Yadav, } \\
\text { 2002) }\end{array}$ \\
\hline
\end{tabular}


The various insect pests susceptible to neem products in leguminous crops is given in Table 3 .

Table 3. The various neem products for the control of insect pests in Leguminous crops

\begin{tabular}{cllll}
\hline S.N. & Crops & Products used & Pests & References \\
\hline 1. & Chickpea & $\begin{array}{l}\text { 5\% Neem seed } \\
\text { kernel extract }\end{array}$ & Helicoverpa armigera & (Kumar et al., 2019) \\
\hline 2. & Greengram & Neem leaf powder & Callosobruchus maculatus & (Gupta et al., 2015) \\
\hline 3. & Cowpea & Neem seed Extract & Cow pea Bruchid & $\begin{array}{l}\text { (Lale \& Mustapha, } \\
\text { 2000) }\end{array}$ \\
\cline { 3 - 5 } & & $\begin{array}{l}\text { Neem + Metarhizium } \\
\text { anisople }\end{array}$ & $\begin{array}{l}\text { Cowpea thrips } \\
\text { (Megolurothipss jostedti ) }\end{array}$ & (Raoul et al., 2019) \\
\hline 4. & Pea & $\begin{array}{l}\text { Neem seed kernel } \\
\text { extract }\end{array}$ & $\begin{array}{l}\text { Pea aphid } \\
\text { (Melesse, 2012) }\end{array}$ & (Joshi et al., 2016) \\
\hline 5. & Sorghum & $2 \%$ Neem oil & $\begin{array}{l}\text { Sorghum shoot fly } \\
\text { (Atherigona soccata } \\
\text { Rondani) }\end{array}$ & \\
\hline
\end{tabular}

\section{Ingredients found in neem}

A broad number of active compounds have been extracted from neem the major extracts are divided into two constituents as terpenoids, which include protolimonoids, limonoids, pentatriterpenoids and hexatriterpenoids, and non terpenoids as hydrocarbons, fatty acids, steroids, phenols, flavonoids, and other (Schmutterer, 1995).

Neem seed kernel contain significant amount of limonoids where azadiracthin $\left(\mathrm{C}_{35} \mathrm{H}_{44} \mathrm{O}_{16}\right)$ is the most active one and the other major limonoids are: salanin, meliantriol, and nimbin that contain insecticidal and pesticidal properties (Hashmat et al., 2012). Other bioactive compounds present in neem includes, salannol, nimbin, nimbinin, nimbidin, nimbidiol, 3-tigloylazadirachtol (azadirachtin B), and 1tigloyl-3-acetyl1-hydroxymeliacarpin (Azadirachtin D) (Mongkholkhajornsilp et al., 2005; Morgan, 2009; Melwita \& Ju, 2010). These compounds are known to have an important role in regulating the activities of pests.

More than 200 compounds can be extracted from neem (Koul \& Wahab, 2004), where azadirachtin (Az) is the most active compound of neem (Khan et al., 2015). It is the component of neem oil, leaves, flowers, and fruits with insecticidal properties (Akhtar et al., 2008). Azadirachtin is found in several forms (A to $\mathrm{K}$ )
(Rangiah \& Gowda, 2019). It is used as anti-viral, anti-fungal, antibacterial and insecticidal residences for many years (Chopra et al., 1952). Also, it is used as anti-feedant, anti-ovipositional, anti-growth regulating, and anti-fecundity properties for insects and various other arthropods (Morgan, 2009). It consists of different isomers $A Z(A, B, C, D, E, F, G, I, J$, and $K$ ) where $\mathrm{Az} A$ is regarded as the most plentiful and bio active compounds which shows repellent, antifeedent, and insecticidal activity in opposition to a number of insect pests and hence Aza A is used for commercial insecticides (Barceloux et al., 2008).

The neem seed kernel contains an average of $2.05-6.10 \mathrm{~g} \mathrm{~kg}^{-1}$ of azadirachtin (Zongo et al., 1993). However, azadirachtin content differs by varied factors including the extraction process, climatic condition, and genetic factors (Ismadji et al., 2012). Around 30-60 g of Azadirachtin per hectare is enough for warding off the major pests (Koul et al., 2004). The main constituent of neem seed kernels extract is the oil having insecticidal activity which contains $40 \%$ of azadirachtin i.e. the highest amount than of all the other active compound (Morgan, 2009). Azadirachtin obtained from seed is used as antifeedant, growth regulator, and as growth inhibitors of the insects (Akthar et al., 2008). Azadirachtin have various effects on the insects and is effective for over 540 species of insects 
that belongs to the order of Lepidoptera, Diptera, Coleoptera, Homoptera, and Hemiptera (Khan et al., 2015). Besides, having an insecticidal properties azadirachtin is also have the adverse effect against fungi, viruses, nematodes, and protozoans (Mordue, 2010). To a greater extent, the content of Azadirachtin can be increased by the treating it with Arbuscular mycorrhizae (Venkateswarlu et al., 2008). Azadirachtin containing tetran or triterpenoids is like insects' hormones "ecdysones" that plays an efficient role as insect growth regulator that deters the feeding habit of insects and inhibits the ability of insect to molt as it changes from pupa to adult and eventually disrupts the overall life cycle of insects (Rangiah \& Gowda et al., 2019). Azadirachtin is used as an organic biopesticide repellent against thrips, whiteflies, aphids, leaf miners, bugs, and varied number of major pests.

The active ingredient azadirachtin was isolated from the seeds of $A$. indica by David Morgan (Butterworth \& Morgan, 1968) and its full structural determination was completed some 17 years later concurrently in the laboratories of Steven Ley, W Kraus and K Nakanishi (Bilton et al., 1987; Kraus et al., 1987; Turner et al., 1987).

Table 4. The effects of azadirachtin against insect pests

\begin{tabular}{|c|c|c|}
\hline Effects & Target & Mode of action \\
\hline Primary antifeedancy & $\begin{array}{l}\text { Mouthparts and other } \\
\text { chemoreceptorss }\end{array}$ & $\begin{array}{l}\text { Deterrent cell stimulation, sugar cell } \\
\text { inhibition }\end{array}$ \\
\hline Secondary antifeedancy & Guts & $\begin{array}{l}\text { Peristalsis inhibited, enzyme prodcui- } \\
\text { ton reduced }\end{array}$ \\
\hline Insect growth regulation & cuticle & $\begin{array}{l}\text { Alteration to ecdysteroid and JH titres } \\
\text { by blockage of release of morphoge- } \\
\text { netic peptides leading to moulting de- } \\
\text { fects }\end{array}$ \\
\hline Sterility & Reproductive organs & $\begin{array}{l}\text { Alteration to ecdysteroid and JK titres } \\
\text { leading got reduction in number of via- } \\
\text { ble eggs and live progeny }\end{array}$ \\
\hline \multirow[t]{3}{*}{ Cellular processes } & Dividing cells & $\begin{array}{l}\text { Blockage of cell division post metphase } \\
\text { in meiosis and mitosis }\end{array}$ \\
\hline & Muscles & Loss of muscle tone \\
\hline & Cell synthetic machinery & $\begin{array}{l}\text { Blockage of digestive enzyme produc- } \\
\text { tion in gut } \\
\text { Inhibition of protein synthesis in vari- } \\
\text { ous tissues }\end{array}$ \\
\hline
\end{tabular}

(Mordue \& Nisbet, 2000)

The physiological effects of azadirachtin are more consistent than the antifeedant effects, and result from interference with growth and molting, interference with reproduction and interference with cellular processes (Table 4). In all insect species tested dose response effects be reduced growth, increased mortalities, abnormal molts, and delayed molts. These effects are related to disruption of endocrine system controlling growth and molting. The molting effects are due to a disruption in the synthesis and release of ecdysteroids (molting hormone) and other classes of hormones and this can be demonstrated by accurately timed injections of azadirachtin into the haemoulymph of $5^{\text {th }}$ instar nymphs of L. migratoria (Mordue et al., 1986). 
Table 5. The effective dose (ED50) of insects to azadirachtin

\begin{tabular}{lc}
\hline Insect orders & Effective dose (ED50) which causes 50\% inhibition feeding \\
\hline Lepitoptera & $1-50$ \\
\hline Coleiptera & $100-500$ \\
\hline Hemiptera & $100-500$ \\
\hline Hymenoptera & $100-500$ \\
\hline
\end{tabular}

(Mordue \& Nisbet, 2000)

Insects from different Orders differ markedly in their behavior responses to azadirachtin (Table 5). Lepidoptera are extremely sensitive to azadirachtin and show effective antifeedancies from $<1-50 \mathrm{ppm}$, depending upon species. Coleoptera, Hemiptera, and Homoptera are less sensitive to azadirachtin behaviorally with up to $100 \%$ antifeedancy being achieved at $100-500 \mathrm{ppm}$.

\section{Mode and Specificity of Action of Neem oviposition deterrents}

Neem has an ovipositional deterrent activity on many pests that may deter economic value of plants (Acharya et al., 2017). Application of neem formulations has prevented the females from depositing eggs (Roshan \& Verma, 2015). Azadirachtin inhibits the oviposition of the female by disrupting the egg formation or by synthesis of the ecdysteriod (Berxolli \& Shahini, 2017) where in male, it acts as an suspension for forming the meiotic process which result in sperm production (Adnan et al., 2004; Martinez \& Van Emden, 2001). The oviposition deterrence activity of neem can be found against pulse beetle, Callosobruchus chinensis (Akter et al., 2019), cabbage moth, Mamestra brassicae (Jogar et al., 2009), peach fruit-fly ( $B$. Zonata) (Mahmoud \& Shoeib, 2008) and potato tuber moth, Phthorimaea opercullela (El-Sinary \& Rizk, 2002). The addition of neem seed extract and Neem formulations exhibit its oviposition on cauliflower (Shah et al., 2019).

\section{Repellent}

Neem oil alone or mixed with other compounds like coconut oil also exhibit repellency on mosquito (Brahmachari, 2004). Beside its mosquito repellence effect, the use of neem ei- ther in aqueous or in formulated forms was effective on citrus leaf miner (Canarte-Bermudez et al., 2020). Similarly, the higher concentration of azatrol, triple action neem oil and pure neem oil were able to repel aphids feeding on sweet pepper plants (Shannag et al., 2014). Recently, Incense sticks of different herbal products along with neem were made and these sticks on burning were proved to be the most effective to control mosquito (Bahadur et al., 2020).

\section{Antifeedant}

The anti-feedant properties of neem have been able to degrade the numerous insects' pests and protect plants. The mode of action of anti-feedant is that when the insects starve, they try to feed on the parts of the plants treated with neem, its feeding ability starts to deter and as a result insects gets repelled away from the field (Roshan \& Verma, 2015). The presence of azadirachtin, salanin and melandriol generates an antiperistalitic wave in the alimentary canal of insects and this produces something similar to vomiting sensation in the insect. Because of this sensation the insect does not feed on the neem treated surface and ability to swallow is also blocked (Vijayalakshmi et al., 1985). Anifeedant activity of neem can be observed against economically important pest Spodoptera litura as reported by Prianto et al. (2019). Azadirachtin, the most essential compound showing anti-feedant activities, blocks the formation of hormone "ecdysteroid" which is important for carrying out molting in insects (Berxolli \& Shahini, 2017). Similarly, the presence of other compound on neem like salannin and meliantrol discourage feeding behaviour on the pests (Campos et al., 2016). 


\section{Growth regulation}

Different neem extracts show decrease in fertility, growth inhibitory activity and high mortality rate on more than 400 insect species from different orders (Ragsdale et al., 2004; Liu et al., 2004). Neem oil consists of different growth regulating compounds that inhibits the enzyme ecdysone 20-monoxygenase responsible for converting ecdysone to active hormone (Morgan, 2009). The ecdysone controls the molting of different stages (Mordu, 2004). When azadirachtin enters to the body of larva, the activity of endosyne is deteriorated and hence larval moulting can't occur, thus larval mortality will occur after it has reached the pupal stage. In case of lower concentration, the adult emerging from pupae will be $100 \%$ malformed with the formation of chitin inhibited and sterile (Vijayalakshmi et al., 1985). However, the feed stuff taken by the pests determines their ability to for growth and reproduction (Chapman et al., 1998). Azadirachta indica when fed to Spodoptera frugiperda, the weight of the pupa decreased that sooner or later hampers the growth of the insects (Roel et al., 2010). Even the fungus like Aspergillus was inhibited using neem oil (Rodrigues et al., 2019).

\section{Sterility}

Azadirachtin, a nonvolatile compound, when taken by the insects results into blocking the formation of ecdysteriods from the prothoracic gland and finally leads to an incomplete molting showing the sterility of the adult female (Isman, 2006). In addition, NeemAzal-T/S ( $11 \%)$ fed to the male rats which were used as an experimental study exhibit the antifertility effect because of their histopathological differences that affect the seminiferous tubules forming spermatogenesis (Morovati et al., 2009).

The commercially available neem products and their applications as agrochemicals (pesticides) and fertilizers is given in Table 6.

Table 6. The commercial product of neem

\begin{tabular}{ll}
\hline Fertilizers & Agrochemicals \\
\hline Neem urea guard & Azamax \\
\hline Parker neem coat & Neemix 4.5 \\
\hline Ozoneem coat & BioNeem \\
\hline Ozoneem cake & AZA- direct \\
\hline Neem cake & Neem oil \\
\hline Plan "B" organics-neem cake & OzoNeem oil \\
\hline Bio neem oil foliar & Neemazal technical \\
\hline
\end{tabular}

\section{Future prospects of neem}

Botanically derived insecticides have got more and more attention in the recent years because of the natural substances present on it and will play most important role in developing and industrialized country as well in the near future (Dimetry, 2012). Different entomopathogenic fungi in combination with neem oil tested were found to be against vegetable sucking pest (Halder et al., 2013). The use of nanoparticles of neem in combination with other botanicals like citronella were found as effective antifungal activity against phytopathogenic fungi (Ali et al., 2017). Similarly, neem acts as an alternative, sustainable, and eco-friendly component in agriculture with the aim of decreasing the use of overall insecticide, pesticides, and fumigants (Rangiah \& Gowda, 2019). Although the use of neem is safe, various limitation for the use of neem as biopesticide include photosensitivity, volatilization, short shelf life, and slow killing rate (Isman, 2006; Miresmailli \& Isman, 2014). So, on decreasing the photo degradation effect on neem, enhancing its ability against pests in agriculture, use of nano technology in neem could be a promising botanical pesticide on large scale equally benefiting food and cash crops. 


\section{Conclusion}

Neem based pesticides are extensively used in agriculture all over the world. It contains Azadirachtin, which is a predominant pesticidal active ingredient, having ovipositional deterrence, repellence, antifeedent, growth disruption, and sterility against great variety of insect pests. Neem provides a suitable option for developing eco-friendly and sustainable pesticides. Neem products are suitable for integrated pest management because of their nontoxicity behavior to non-target organisms, easy preparation, and compatibility with other by products. So, there is need to educate everyone for judicious use of neem as biopesticide and protect their agricultural crops.

\section{Authors Contribution}

All authors contributed equally to all stages of preparation of this manuscript. Similarly, final version of manuscript was approved by all authors.

\section{Conflict of Interest}

The authors declare no conflicts of interest.

\section{Acknowledgements}

The authors would like to acknowledge Prithu Technical College, Institute of Agriculture and Animal Science (IAAS) for providing all the necessary information required in the preparation of this paper.

\section{References}

Acharya, P., Mir, S. A., \& Nayak, B. (2017). Competence of biopesticide and neem in agriculture. International Journal of Environment, Agriculture and Biotechnology, 2(6), 2958-2964. https://doi.org/10.22161/ijeab/2.6.23

Adnan, S. M., Uddin, M. M., Alam, M. J., Islam, M. S., Kashem, M. A., Rafii, M. Y., \& Latif, M. A. (2014). Management of mango hopper, Idioscopus clypealis, using chemical insecticides and neem oil. The Scientific World Journal, Article 709614. https://doi.org/10.1155/2014/709614

Ahmad, B., Mehmood, N., Sohail, K., Saljoqi, A. U. R., Khan, A., Rab, A., \& Hussain, S. (2019). in vitro management of diamondback moth (Plutella xylostella L.) using different concentrations of parthenium and neem extracts. Journal of Agricultural Science and Technology, 21(3), 659-669.

Ahmad, S., Ansari, M. S., \& Muslim, M. (2015). Toxic effects of neem based insecticides on the fitness of Helicoverpa armigera (Hübner). Crop Protection, 68, 72-78. https://doi.org/10.1016/i.cropro.2014.11.003

Akhtar, Y., Yeoung, Y. R., \& Isman, M. B. (2008). Comparative bioactivity of selected extracts from Meliaceae and some commercial botanical insecticides against two noctuid caterpillars, Trichoplusia ni and Pseudaletia unipuncta. Phytochemistry Reviews, 7(1), 77-88. https://doi.org/10.1007/s11101-0069048-7

Akter, S., Sultana, S., Akter, T., \& Begum, S. (2019). Oviposition deterrent and ovicidal activity of three edible oils (black seed, sesame, and soybean oils) against puls beetle, Callosobruchus chinensis (Lin.) (Coleoptera: Bruchidae) on green gram, Vigna radiata. Bangladesh Journal of Zoology, 47(1), 59-65. https://doi.org/10.3329/bjz.v47i1.42021

Alam, M. J., Ahmed, K. S., Hoque, M., Mansura, A., Rony, M. N. H., \& Haque, M. S. (2019). Bio-efficacy of some bio-pesticides against maize aphid, Rhopalosiphum maidis; a threatening pest of maize. Journal of Science, Technology and Environment Informatics, 8(01), 563-573.

Ali, E. O. M., Shakil, N. A., Rana, V. S., Sarkar, D. J., Majumder, S., Kaushik, P., Shingh, B. B., \& Kumar, J. (2017). Antifungal activity of nano emulsions of neem and citronella oils against phytopathogenic fungi, Rhizoctonia solani and Sclerotium rolfsii. Industrial crops and products, 108, 379-387. https://doi.org/10.1016/j.indcrop.2017.06.061

Anjorin, S. T., Salako, E. A., \& Ndana, R. W. (2004). In vitro assessment of some plants leaf extracts for the control of Meloidogyne spp. and Rhizoctonia solani. Zuma. Journal of Pure and Applied Science, 7(1), 2005.

Aziz, E., \& Khoso, A. G. (2019). Evaluation of repellency of plant-derived insecticide against brinjal and pepper pest populations. International Research Journal of Insect Sciences, 4(1), 1-18

Bahadur, A., Chandrashekar, K. S., \& Pai, V. (2020). Formulation and development of polyherbal mosquito repellent incense sticks. Research Journal of Pharmacy and Technology, 13(1), 124-128. https://doi.org/10.5958/0974-360X.2020.00025.6

Bahar, M. H., Islam, A., Mannan, A., \& Uddin, J. (2007). Effectiveness of some botanical extracts on bean 
aphids attacking yard-long beans. Journal of Entomology, 4(2), 136-142.

https://doi.org/10.3923/je.2007.136.142

Bajwa, A. A., \& Ahmad, A. (2012). Potential applications of neem based products as biopesticides. The Health, 3(4), 116-120.

Barceloux, D. G. (2008). Medical toxicology of natural substances: foods, fungi, medicinal herbs, plants, and venomous animals. John Wiley \& Sons.

Basedow, T., Ossiewatsch, H. R., Vega, J. B., Kollmann, S., Shafie, H. E., \& Nicol, C. M. Y. (2002). Control of aphids and whiteflies (Homoptera: Aphididae and Aleyrodidae) with different neem preparations in laboratory, greenhouse and field: effects and limitations. Journal of Plant Diseases and Protection, 612623. https://www.jstor.org/stable/43215484

Benelli, G., \& Pavela, R. (2018). Repellence of essential oils and selected compounds against ticks-a systematic review. Acta Tropica, 179, 47-54. https://doi.org/10.1016/i.actatropica.2017.12.025

Benelli, G., Bedini, S., Cosci, F., Toniolo, C., Conti, B., \& Nicoletti, M. (2015). Larvicidal and ovideterrent properties of neem oil and fractions against the filariasis vector Aedes albopictus (Diptera: Culicidae): a bioactivity survey across production sites. Parasitology Research, 114(1), 227-236. http://dx.doi.org/10.1007/s00436-014-4183-3

Berxolli, A., \& Shahini, S. (2017). Azadirachtin, a useful alternative for controlling Tuta absoluta (Myerick). European Journal of Physical and Agricultural Sciences, 5(2), 40-45.

Bhatta, K., Chaulagain, L., Kafle, K., \& Shrestha, J. (2019). Bio-Efficacy of plant extracts against mustard aphid (Lipaphis erysimi Kalt.) on rapeseed (Brassica campestris Linn.) under field and laboratory conditions. Syrian Journal of Agricultural Research, 6(4), 557566

Bilton, J. N., Broughton, H. B., Jones, P. S., Ley, S. V., Lidert, Z., Morgan, E. D., Rzepa, H. S., Sheppard, R. N., Slawin, A. M. Z., \& Williams, D. J. (1987). An X-ray crystallographic, mass spectroscopic, and NMR study of the limonoid insect antifeedant azadirachtin and related derivatives. Tetrahedron, 43, 2805-2815.

Boulahbel, B., Aribi, N., Kilani-Morakchi, S., \& Soltani, N. (2015). Activity of neem oil in Drosophila melanogaster: toxicity and delayed effect on the progeny. Journal of Entomology and Zoology Studies, 3, 306310.
Brahmachari, G. (2004). Neem-an omnipotent plant: a retrospection. Chembiochem, 5(4), 408-421. https://doi.org/10.1002/cbic.200300749

Bushra, S., Tariq, M., Naeem, M., \& Ashfaq, M. (2014). Efficacy of neem oil and turmeric powder against Sitobion avenae and Rhopalosiphum padi. International Journal of Biosciences, 5 (12), 439-448.

Butterworth, J. H., \& Morgan, E. D. (1968). Isolation of a substance that suppresses feeding in locusts. Chemical Communications (London), (1), 23-24. https://doi.org/10.1039/C19680000023

Campos, E. V., de Oliveira, J. L., Pascoli, M., de Lima, R., \& Fraceto, L. F. (2016). Neem oil and crop protection: from now to the future. Frontiers in plant science, 7 , 1494. https://doi.org/10.3389/fpls.2016.01494

Cañarte-Bermúdez, E., Navarrete-Cedeño, B., MonteroCedeño, S., Arredondo-Bernal, H. C., Chávez-López, 0., \& Bautista-Martínez, N. (2020). Effect of neem on Phyllocnistis citrella Stainton and its parasitoid Ageniaspis citricola Logvinovskaya in Ecuador. Enfoque UTE, 11(2), pp. 01-10.

https://doi.org/10.29019/enfoque.v11n2.519

Chandramohan, B., Murugan, K., Madhiyazhagan, P., Kovendan, K., Kumar, P. M., Panneerselvam, C., Dinesh, D., Subramaniam, J., Rajaganesh, R., Nicoletti. M., Canale, A., \& Benelli, J. (2016). Neem byproducts in the fight against mosquito-borne diseases: Biotoxicity of neem cake fractions towards the rural malaria vector Anopheles culicifacies (Diptera: Culicidae). Asian Pacific Journal of Tropical Biomedicine, 6(6), 472-476. https://doi.org/10.1016/i.apitb.2015.11.013

Chapman, R. F., \& Chapman, R. F. (1998). The insects: structure and function. Cambridge University Press.

Chaudhary, S., Kanwar, R. K., Sehgal, A., Cahill, D. M., Barrow, C. J., Sehgal, R., \& Kanwar, J. R. (2017). Progress on Azadirachta indica based biopesticides in replacing synthetic toxic pesticides. Frontiers in Plant Science, 8, 610. https://doi.org/10.3389/fpls.2017.00610

Chopra, I. C., Gupta, K. C., \& Nazir, B. N. (1952). Preliminary study of anti-bacterial substances from Melia azidirachta. The Indian Journal of Medical Research, 40(4), 511.

Choudhary, R., Chandrakar, G., Bhardwaj, J. R., Khan, H. H., \& Sahu, R. (2017). Assessment of the efficacy of neem based insecticides for the management of yellow stem borer, Scirpophaga incertulas Walk in paddy field. Journal of Pharmacognosy and Phytochemistry, 6(5), 1446-1449. 
Copping, L. G., \& Menn, J. J. (2000). Biopesticides: a review of their action, applications and efficacy. Pest Management Science: Formerly Pesticide Science, 56(8), 651-676. https://doi.org/10.1002/1526$\underline{4998}$

da Silva, F. A., \& Martinez, S. S. (2004). Effect of neem seed oil aqueous solutions on survival and development of the predator Cycloneda sanguinea (L.) (Coleoptera: Coccinellidae). Neotropical Entomology, 33(6), 751-757. https://doi.org/10.1590/S1519$\underline{566 X 2004000600013}$

Damalas, C. A., \& Eleftherohorinos, I. G. (2011). Pesticide exposure, safety issues, and risk assessment indicators. International Journal of Environmental Research and Public Health, 8(5), 1402-1419. https://doi.org/10.3390/ijerph8051402

Das, S. K., \& Avasthe, R. (2020). Packages of organic nutrient management as soil policy for upgrading cropping system to restore soil productivity. Organic Agriculture. https://doi.org/10.5772/intechopen.91928

Das, S. K., Avasthe, R. K., Singh, M., \& Roy,A. (2018). Managing soil fertility under organic production system through integrated approach. Green Farming, 9(3), 449-454.

Dash, S., Mohapatra, L. N., Swain, S., \& Swain, D. K. (2019). Bio-efficacy of newer insecticides in combination with neem product against plant hoppers of rice. Journal of Entomology and Zoology Studies, 7(1), 1152-1155.

Debashri, M., \& Tamal, M. (2012). A Review on efficacy of Azadirachta indica A. Juss based biopesticides: An Indian perspective. Research Journal of Recent Sciences, 1(3), 94-99

Dimetry, N. Z. (2012). Prospects of botanical pesticides for the future in integrated pest management programme (IPM) with special reference to neem uses in Egypt. Archives of Phytopathology and Plant Protection, 45(10), 1138-1161.

Djenontin, T. S., Wotto, V. D., Avlessi, F., Lozano, P., Sohounhloué, D. K., \& Pioch, D. (2012). Composition of Azadirachta indica and Carapaprocera (Meliaceae) seed oils and cakes obtained after oil extraction. Industrial Crops and Products, 38, 39-45. https://doi.org/10.1016/i.indcrop.2012.01.005

Dua, V. K., Pandey, A. C., Raghavendra, K., Gupta, A., Sharma, T., \& Dash, A. P. (2009). Larvicidal activity of neem oil (Azadirachta indica) formulation against mosquitoes. Malaria Journal, 8(1), https://doi.org/10.1186/1475-2875-8-124
El-Sinary, N., \& Rizk, A. (2002). Oviposition deterrence and other biological influences of aqueous leaves and extracts of neem, colocasia, and their mixtures alone or combine with gamma radiation to reduce the risk of the potato tubermoth, Phthorimae operculella (Zeller). Pakistan Journal of Bioscience, 5(9), 911-914.

https://doi.org/10.3923/pjbs.2002.911.914

El-Wahab, A. A., El-Wahab, A., Horia, A., Abdel-Hameed, N. A., Abohatab, E. E., \& Hager, M. (2019). Effect of some materials for controlling green peach aphid, Myzuspersicae (Sulzer). Journal of Plant Protection and Pathology, 10(2), 111-113.

Gajalakshmi, S., \& Abbasi, S. A. (2004). Neem leaves as a source of fertilizer-cum-pesticide vermicompost. Bioresource Technology, 92(3), 291-296. https://doi.org/10.1016/j.biortech.2003.09.012

Gosse, B., Amissa, A. A., AnohAdje, F., BobeleNiamke, F., Ollivier, D., \& Ito, Y. (2005). Analysis of components of neem (Azadirachta indica) oil by diverse chromatographic techniques. Journal of Liquid Chromatography \& Related Technologies, 28(14), 22252233. http://doi.org/10.1081/ILC-200064164

Gupta, S. C., Prasad, S., Tyagi, A. K., Kunnumakkara, A. B., \& Aggarwal, B. B. (2017). Neem (Azadirachta indica): an indian traditional panacea with modern molecular basis. Phytomedicine, 34, 14-20. https://doi.org/10.1016/i.phymed.2017.07.001

Gupta, S., \& Dikshit, A. K. (2010). Biopesticides: An ecofriendly approach for pest control. Journal of Biopesticides, 3(Special Issue), 186.

Gupta, S., Apte, S. D., \& Wast, N. (2015). Efficacy of some plant material on green gram [Vigna radiata (L.) Wilczek] seed against Callosobruchus maculatus (Fab.). European Journal Appllied Science, 7, 21-24.

Halder, J., Rai, A. B., \& Kodandaram, M. H. (2013). Compatibility of neem oil and different entomopathogens for the management of major vegetable sucking pests. National Academy Science Letters, 36(1), 19-25.

Hashmat, I., Azad, H., \& Ahmed, A. (2012). Neem (Azadirachta indica A. Juss)-A nature's drugstore: an overview. International Research Journal of Biological Sciences, 1(6), 76-79.

Hossain, M. A., \& Nagooru, M. R. (2011). Biochemical profiling and total flavonoids contents of leaves crude extract of endemic medicinal plant Corydyline terminalis L. Kunth. Pharmacognosy Journal, 3(24), 2530. https://doi.org/10.5530/pj.2011.24.5 
Illakwahhi, D., \& Srivastava, B. B. (2019). Improving the efficacy of abamectin using neem oil in controlling tomato leafminers, Tuta absoluta (Meyrick). Advanced Journal of Chemistry, Section A: Theoretical, Engineering and Applied Chemistry, 2(3), 216-224.

Ismadji, S., Kurniawan, A., Ju, Y. H., Soetaredjo, F. E., Ayucitra, A., \& Ong, L. K. (2012). Solubility of azadirachtin and several triterpenoid compounds extracted from neem seed kernel in supercritical $\mathrm{CO}_{2}$. Fluidphase Equilibria, 336, 9-15. https://doi.org/10.1016/i.fluid.2012.08.026

Isman, M. B. (2006). Botanical insecticides, deterrents, and repellents in modern agriculture and an increasingly regulated world. Annual Review of Entomology, 51, 45-66. http://doi.org/10.1146/annurev.ento.51.110104.151146

Jahan, A. M. M., Bachchu, M. A. A., Rahman, M. H., Ara, R., \& Al Helal, M. M. (2019). Bioactivities of four botanical extracts against rice. Journal of Science and Technology, 32, 44.

Javed, N., Gowen, S. R., Inam-ul-Haq, M., \& Anwar, S. A. (2007). Protective and curative effect of neem ( $\mathrm{Aza}$ dirachta indica) formulations on the development of root-knot nematode Meloidogyne javanica in roots of tomato plants. Crop Protection, 26(4), 530534

Jogar, K., Metspalu, L., Hiiesaar, K., Loorits, L., Ploomi, A., Kiosk, A., \& Luik, A. (2009). Influence of neem Azalea-T/S on Mamestra brassicae L. SodininkysteIrDarzininkyste. Lithuanian Institute of Horticulture, 28 (3), 85-92.

Joshi, S., Hussain, T., Kirar, V. S. \& Nagar, R. (2016). Management of sorghum shoot fly, Atherigona soccata Rondani (Diptera:Muscidae) through botanicals. Journal of Biopesticides, 9 (1), 23-26.

Kala, S., Naik, S. N., Patanjali, P. K., \& Sogan, N. (2019). Neem oil water dispersible tablet as effective larvicide, ovicide and oviposition deterrent against Anopheles culicifacies. South African Journal of Botany, 123, 387-392.

https://doi.org/10.1016/j.sajb.2019.03.033

Kamaraj, C., Gandhi, P. R., Elango, G., Karthi, S., Chung, I. M., \& Rajakumar, G. (2017). Novel and environmental friendly approach; impact of neem ( $\mathrm{Aza}$ dirachta indica) gum nano formulation (NGNF) on Helicoverpa armigera (Hub.) and Spodoptera litura (Fab.). International Journal of Biological Macromolecules, 107, 59-69.1. http://doi.org/0.1016/i.ijbiomac.2017.08.145

Kaverimanian, V., \& Heuertz, R. M. (2020). Effects of neem extracts on formed biofilm of Pseudomonas aeruginosa. The Federation of American Societies for Experimental Biology (FASEB) Journal, 34(S1), 1-1. https://doi.org/10.1096/fasebj.2020.34.s1.05737

Ketkar, C. M. (2000). Use of neem (Azadirachta Indica A Juss) and its by products in organic farming. In Ketkar (Eds.)., Practice oriented results on use and production of neem-ingredients and pheromones, Proceedings of the 9th Workshop (pp. 31-38).

Khan, J., Anjum, S. I., Khan, I., Rehman, F. U., \& Khan, A. (2015). Larvicidal \& development retarding effects of hexane crude extract of Otostegia limbata on 3rd instar larvae of Drosophila melanogaster meign (Diptera: Drosophilidae). Journal of Entomology and Zoology Studies, 3(1), 06-09.

Khanal, S., Adhikari, A., Tiwari, A., Singh, N. B., \& Subedi, R. (2019). Efficiency of botanical extract against maize weevil Sitophilus zeamais (Motschulsky, 1855) (Coleoptera: Curculionidae). World News of Natural Sciences, 24, 1-8

Koul 0., \& Wahab S. (2004) Neem biotechnology - A Synthesis. In: Koul O., Wahab S. (eds) Neem: today and in the new millennium. Springer, Dordrecht. https://doi.org/10.1007/1-4020-2596-3 12

Kovaříková, K., \& Pavela, R. (2019). United forces of botanical oils: Efficacy of neem and karanja oil against colorado potato beetle under laboratory conditions. Plants, 8(12), 608.

Kraiss, H., \& Cullen, E. M. (2008). Insect growth regulator effects of azadirachtin and neem oil on survivorship, development and fecundity of Aphis glycines (Homoptera: Aphididae) and its predator, Harmonia axyridis (Coleoptera: Coccinellidae). Pest Management Science: formerly Pesticide Science, 64(6), 660-668.

Kraus, W., Bokel, M., Bruhn, A., Cramer, R., Klaiber I., Klenck, A., Nagl, G., Pöhnl, H., Sadlo, H., \& Vogler, B. (1987). Structure determination by NMR of azadirachtin and related compounds from Azadirachta indica (Meliaceae). Tetrahedron, 43, 2817-2830.

Krishnaiah, D., Sarbatly, R., \& Bono, A. (2007). Phytochemical antioxidants for health and medicine a move towards nature. Biotechnology and Molecular Biology Reviews, 2(4), 97-104.

Kumar, A., Tripathi, M. K., Chandra, U., \& Veer, R. (2019). Efficacy of botanicals and bio-pesticide against Helicoverpa armigera in chickpea. Journal of Entomology and Zoology Studies, 7(1), 54-57.

Kumar, N., Pathera, A. K., Saini, P., \& Kumar, M. (2012). Harmful effects of pesticides on human health. Annals of Agri-Bio Research, 17, 125-127. 
Kumar, U. S. U., Paridah, M. T., Owolabi, F. T., Gopakumar, D. A., Rizal, S., Amirul, A. A., ...\& Khalil, H. A. (2019). Neem leaves extract based seaweed bio-degradable composite films with excellent antimicrobial activity for sustainable packaging material. BioResources, 14(1), 700-713.

Kumar, V. S., \& Navaratnam, V. (2013). Neem (Azadirachta indica): Prehistory to contemporary medicinal uses to humankind. Asian Pacific Journal of Tropical Biomedicine, 3(7), 505-514. http://doi.org/10.1016/S2221-1691(13)60105-7

Kumari, S., \& Yadav, R. P. (2002). Effect of some phytoextracts on the coriander aphid, Hyadaphis coriandari (Das) (Homoptera: Aphididae) and its Coccinellid (Coleoptera: Coccinellidae) predator in coriander ecosystem. Journal of Aphidology, 16, 167- 173.

Lale, N. E., \& Mustapha, A. (2000). Potential of combining neem (Azadirachta indica A. Juss) seed oil with varietal resistance for the management of the cowpea bruchid, Callosobruchus maculatus (F). Journal of Stored Products Research, 36(3), 215-22.

Liu, J., Wu, K., Hopper, K. R., \& Zhao, K. (2004). Population dynamics of Aphis glycines (Homoptera: Aphididae) and its natural enemies in soybean in northern China. Annals of the Entomological Society of America, 97(2), 235-239.

Lokanadhan, S., Muthukrishnan, P., \& Jeyaraman, S. (2012). Neem products and their agricultural applications. Journal of Biopesticides, 5, 72-76.

Macintosh, S.. (2017). Agriculture in the Modern Age Biopesticides and Plant Biotechnology. Women in Sustainable Agriculture and Food Biotechnology. Springer International Publishing. 59-69.

Madhu, B., Warghat, A. N., \& Tayde, A. R. (2020). Comparative effect of bio pesticides and neem commercial products on rice yellow stem borer, Scirpophaga incertulas (Walker). Journal of Entomology and Zoology Studies, 8 (1), 758-760.

Mahmoud, M. F., \& Shoeib, M. A. (2008). Sterilant and ovipositor deterrent activity of neem formulation on peach fruit fly Bactrocera zonata (Saunders) (Diptera: Tephritidae). Journal of Biopesticides, 1, 177-181.

Manikandan, P., Letchoumy, P. V., Gopalakrishnan, M., \& Nagini, S. (2008). Evaluation of Azadirachta indica leaf fractions for in vitro antioxidant potential and in vivo modulation of biomarkers of chemoprevention in the hamster buccal pouch carcinogenesis model. Food and Chemical Toxicology, 46(7), 23322343. http://doi.org/10.1016/i.fct.2008.03.013
Martinez, S. S., \& Van Emden, H. F. (2001). Growth disruption, abnormalities and mortality of Spodoptera littoralis (Boisduval)(Lepidoptera: Noctuidae) caused by azadirachtin. Neotropical Entomology, 30(1), 113-125.

https://doi.org/10.1590/S1519566X2001000100017

Matharu, K. S., \& Tanwar, P. S. (2019). Efficacy of different insecticides and biopesticide against wheat aphid. Journal of Entomology and Zoology, 7(3), 521-524.

Mazid, S., Kalida, J. C., \& Rajkhowa, R. C. (2011). A review on the use of biopesticides in insect pest management. International Journal of Science and Advanced Technology, 1, 169-178.

Melesse, T., \& Singh, S. K. (2012). Effect of climatic factors on pea aphid, Acyrthosiphon pisum Harris (Homoptera: Aphididae) population and its management through planting dates and biopesticides in field pea (Pisum sativum L.). Journal of Agricultural Technology, 8(1), 125-132.

Melwita, E., \& Ju, Y. H. (2010). Separation of azadirachtin and other limonoids from crude neem oil via solvent precipitation. Separation and Purification Technology, 74(2), 219-224. https://doi.org/10.1016/i.seppur.2010.06.008

Miresmailli, S., \& Isman, M. B. (2014). Botanical insecticides inspired by plant-herbivore chemical interactions. Trends in plant science, 19, 29-35. https://doi.org/10.1016/i.tplants.2013.10.002

Mohapatra, A., Mahalik, J. K., Dash, B. K., \& Samal, B. K. (2020). Eco-friendly management of Meloidogyne incognita in okra through AM fungus (Glomus fasciculatum) and neem oil cake. Annals of Plant Protection Sciences, 28(1), 76-79. http://doi.org/10.5958/0974-0163.2020.00018.X

Mohapatra, L. N. (2018). Field evaluation of ITKs against insect pests of rice. Indian Journal of Traditional Knowledge, 17(2), 360-364.

Mongkholkhajornsilp, D., Douglas, S., Douglas, P. L., Elkamel, A., Teppaitoon, W., \& Pongamphai, S. (2005). Supercritical CO2 extraction of nimbin from neem seeds-a modelling study. Journal of Food Engineering, 71(4), 331-340. http://doi.org/:10.1016/i.jfoodeng.2004.08.007

Mordue, A. J., \& Nisbet, A. J. (2000). Azadirachtin from the neem tree Azadirachta indica: its action against insects. Anais da Sociedade Entomológica do Brasil, 29(4), 615-632. 
Mordue, A. J., Evans. K. A., \& Charlet, M. (1986). Azadirachtin, ecdysteroids and ecdysis in Locusta migratoria. Comparative Biochemistry and Physiology, 85c, 297-301.

Mordue, A. J. (2004). Present concepts of the mode of action of azadirachtin from neem. In O. Koul \& Wahab S. (Eds.), Neem: Today and in the New Millennium. (pp 229-242). Springer, Dordrecht. https://doi.org/10.1007/1-4020-2596-311

Mordue, A. J., Morgan, E. D., \& Nisbet, A. J. (Eds.) (2010). Azadirachtin, a natural product in insect control. Comprehensive Molecular Insect Science (Vol 4). Biochemistry and Molecular Biology.

Morgan, E. D. (2009). Azadirachtin, a scientific gold mine. Bioorganic and Medicinal Chemistry, 17(12), 40964105. https://doi.org/10.1016/i.bmc.2008.11.081

Morovati, M., Mahmoudi, M., Ghazi-Khansari, M., Jabbari, L., \& Khalilaria, A. (2009). Sterility effect of the commercial neem extract NeemAzal-T/ $\mathrm{S}^{\wedge} \AA(A z a-$ dirachta indica A. Jus.) on male rats (Rattus norvegicus). Turkish Journal of Zoology, 33(2), 201-206. http://doi.org/10.3906/zoo-0709-6

Nathan, S. S., Choi, M. Y., Seo, H. Y., Paik, C. H., Kalaivani, K., \& Kim, J. D. (2008). Effect of azadirachtin on acetylcholinesterase (AChE) activity and histology of the brown planthopper Nilaparvata lugens (Stål). Ecotoxicology and Environmental Safety, 70(2), 244250.

https://doi.org/10.1016/i.ecoenv.2007.07.005

Nathan, S. S., Kalaivani, K., Chung, P. G., \& Murugan, K. (2006). Effect of neem limonoids on lactate dehydrogenase (LDH) of the rice leaffolder, Cnaphalocrocis medinalis (Guenée)(Insecta: Lepidoptera: Pyralidae). Chemosphere, 62(8), 1388-1393. http://doi.org/10.1016/i.chemosphere.2005.07.009

Nicoletti, M., Mariani, S., Maccioni, O., Coccioletti, T., \& Murugan, K. (2012). Neem cake: chemical composition and larvicidal activity on Asian tiger mosquito. Parasitology research, 111(1), 205-213. http://doi.org/10.1007/s00436-012-2819-8

Olabinri, B. M., Adepoju, E. A., Zainab, A. A., \& Ahmed, A. A. (2014). Phytochemical profiling of phytoconstituents of grape, Jatropha curcas and Neem (Azadirachta indica) extracts. Journal of Pharmacognosy and Phytotherapy, 6(2), 17-23. http://doi.org/10.5897//PP2013.0308

Parajuli, S., Shrestha, J., \& Ghimire, S. (2020). Organic farming in Nepal: A viable option for food security and agricultural sustainability. Archives of Agriculture and Environmental Science, 5(2), 223-230. https://dx.doi.org/10.26832/24566632.2020.0502 $\underline{021}$

Pareet, J. D. (2006). Biorational approaches for the management of brinjal shoot and fruit borer. (M. Sc. (Agri.) Thesis, University of Agricultural Sciences, Dharwad, Karnataka, India).

Pascoli, M., Jacques, M. T., Agarrayua, D. A., Avila, D. S., Lima, R., \& Fraceto, L. F. (2019). Neem oil based nanopesticide as an environmentally-friendly formulation for applications in sustainable agriculture: An ecotoxicological perspective. Science of the Total Environment, 677, 57-67. http://doi.org/10.1016/j.scitotenv.2019.04.345

Prianto, A. H., Budiawan, N. F. N., Yulizar, Y., \& Simanjuntak, P. (2019). The synergy effect of azadirachtin and minor components of neem seed oil on antifeedant activity of Spodoptera litura. Buletin Penelitian Tanaman Rempah dan Obat, 30(1), $27-$ 34. http://doi.org/10.21082/bullittro.v30n1.2019.27-34

Ragsdale, D. W., Voegtlin, D. J., \& O'neil, R. J. (2004). Soybean aphid biology in North America. Annals of the Entomological Society of America, 97(2), 204-208. http://doi.org/10.1603/00138746(2004)097[0204:SABINA]2.0.CO;2

Raizada, R. B., Srivastava, M. K., Kaushal, R. A., \& Singh, R. P. (2001). Azadirachtin, a neem biopesticide: subchronic toxicity assessment in rats. Food and Chemical Toxicology, 39(5), 477-483.

Rakibuzzaman, M., Mahato, A. K., Husna, M. A., Maliha, M., \& Jamal Uddin, A. F. M. (2019). Influence of natura one and neem oil on growth and yield of brinjal ( $\mathrm{So}$ lanum melongena). Journal of Bioscience and Agriculture Research, 20(02), 1694-1699.

Ramachandran, S., Singh, S. K., Larroche, C., Soccol, C. R., \& Pandey, A. (2007). Oil cakes and their biotechnological applications-A review. Bioresource Technology, 98(10), 2000-2009. http://doi.org/10.1016/i.biortech.2006.08.002

Rangiah K., \& Gowda M. (2019). Method to quantify plant secondary metabolites: quantification of neem metabolites from leaf, bark, and seed extracts as an example. In: Gowda M., Sheetal A., Kole C. (Ed.), The Neem Genome. Compendium of Plant Genomes. (pp 21-30). Springer International Publishing. https://doi.org/10.1007/978-3-030-16122-4_3

Raoul, B. B., Albert, N., Manuele, T., \& Nchiwan, N. E. (2019). The incidence of aqueous neem leaves (Azadirachta indica A. Juss) extract and Metarhizium anisopliae Metch. on cowpea thrips (Mego- 
lurothips sjostedti Trybom) and yield in Ngaoundéré (Adamaoua-Cameroun). Journal of Zoology and Entomology Studies, 7(5), 333-338

Ricci, F., Berardi, V., \& Risuleo, G. (2009). Differential cytotoxicity of MEX: a component of neem oil whose action is exerted at the cell membrane level. Molecules, 14(1), 122-132.

https://doi.org/10.3390/molecules14010122

Rodrigues, M. P., Astoreca, A. L., Oliveira, Á. A. D., Salvato, L. A., Biscoto, G. L., Keller, L. A. M., \& Keller, K. M. (2019). In vitro activity of neem (Azadirachta indica) oil on growth and Ochratoxin A Production by Aspergillus carbonarius isolates. Toxins, 11(10), 579. http://doi.org/10.3390/toxins11100579

Roel, A. R., Dourado, D. M., Matias, R., Porto, K. R., Bednaski, A. V., \& Costa, R. B. D. (2010). The effect of sub-lethal doses of Azadirachta indica (Meliaceae) oil on the midgut of Spodoptera frugiperda (Lepidoptera, Noctuidae). Revista Brasileira de Entomologia, 54(3), 505-510.

http://dx.doi.org/10.1590/S008556262010000300024

Roshan, A., \& Verma, N. K. (2015). A brief study on neem (Azarrdirachta indica A.) and its application-A review. Research Journal of Phytomedicine, 1(1), 0103.

Salako, E. A. (2002). Plant protection for the resourcepoor farmers: A key note address at the Nigerian Society for Plant Protection. 30th Annual conference. UNAAB. Abeokuta Sept. 1st-4th, 2002.

Saleem, M. S., Batool, T. S., Akbar, M. F., Raza, S., \& Shahzad, S. (2019). Efficiency of botanical pesticides against some pests infesting hydroponic cucumber, cultivated under greenhouse conditions. Egyptian Journal of Biological Pest Control, 29 (1), 37. https://doi.org/10.1186/s41938-019-0138-4

Sara, J. B., Marelle, G. B., Gerrit, M. A., Joop, J. A. L., Huis, A., Dicke, M., \& Rietjens, I. M. C. M. (2004). Safety evaluation of neem (Azadirachta indica) derived pesticides. Journal of Ethnopharmacology, 94, 25-41. http://doi.org/10.1016/i.jep.2004.05.011

Sathyan, T., Elanchezhyan, K., \& Murugesan, N. (2020). Pests of black pepper and their management. Biotica Research Today, 2(4), 87-89.

Schmutterer, H. (1990). Properties and potential of natural pesticides from the neem tree, Azadirachta indica. Annual Review of Entomology. 35, 271-297.

Schmutterer, H. (1995). The neem tree, Azadirachta indica A. Juss. and other meliaceous plants: source of unique natural products for integrated pest management, medicine, industry and other purposes.
Nematologica, 43(1), 121-122.

https://doi.org/10.1163/004725997X00098

Schmutterer, H. (2002). The neem tree, Azadirachta indica A. Juss. and other Meliaceous plants: Sources of unique natural products for integrated pest management, medicine, industry and other purposes, (2nd ed.). Neem Foundation, Mumbai, India.

Schmutterer, H., \& Singh, R. P. (1995). List of insect pests susceptible to neem products. The neem tree: Azadirachta indica A. Juss and other Meliaceae plants. VCH, New York.

Senthil-Nathan, S., Choi, M. Y., Seo, H. Y., Paik, C. H., \& Kalaivani, K. (2009). Toxicity and behavioral effect of $3 \beta, 24,25$-trihydroxycycloartane and beddomei lactone on the rice leaffolder Cnaphalocrocis medinalis (Guenée) (Lepidoptera: Pyralidae). Ecotoxicology and Eenvironmental Safety, 72(4), 1156-1162. http://doi.org/10.1016/i.ecoenv.2008.02.005

Shah, F. M., Razaq, M., Ali, Q., Shad, S. A., Aslam, M., \& Hardy, I. C. (2019). Field evaluation of synthetic and neem-derived alternative insecticides in developing action thresholds against cauliflower pests. Scientific Reports, 9(1), 1-13. http://doi.org/10.1038/s41598-019-44080-y

Shaiba, Z., Amoore, B., Amoore, I., \& Renne, E. (2019). Assessing the impact of neem on fall armyworm damage to maize crops: a field-based study in Nabdam District, UER, Ghana. Journal of Agriculture and Sustainability, 12(2),185-201.

Shannag, H. S., Capinera, J. L., \& Freihat, N. M. (2014). Efficacy of different neem-based biopesticides against green peach aphid, Myzus persicae (Hemiptera: Aphididae). International Journal of Agricultural Policy and Research, 2(2), 61-68

Silva, M. S., Broglio, S. M. F., Trindade, R. C. P., Ferrreira, E. S., Gomes, I. B., \&. Micheletti, L. B. (2015). Toxicity and application of neem in fall armyworm. Comunicata Scientiae, 6(3), 359-364. http://doi.org/10.14295/CS.v6i3.808

Singh, B., \& Singh, N. (2019). In vitro efficacy of botanical extracts, bioagents and insecticide against Brevicoryne brassicae on Brassica oleracea. Annals of Plant Protection Sciences, 27(1), 45-48.

Singh, B., Singh, N., \& Singh, S. (2019). Efficacy Of neem based bopesticide and chemical insecticide against Spodoptera litura on cauliflower under field condition in Gurugram district of Haryana. Plant Archives, 19(2),30339-30342 
Sirohi, A., \& Tandon, P. (2014). Insecticidal effects of various parts of Azadirachta indica on adults of Aulacophora foveicollis (Lucas) (Coleoptera: Chrysomelidae). Trends in Biosciences, 7, 3947-3949.

Tan, Q. G., \& Luo, X. D. (2011). Meliaceous limonoids: chemistry and biological activities. Chemical Reviews, 111(11), 7437-7522.

http://doi.org/10.1021/cr9004023

Tavares, W. S., Costa, M. A., Cruz, I., Silveira, R. D., Serrao, J. E., \& Zanuncio, J. C. (2010). Selective effects of natural and synthetic insecticides on mortality of Spodoptera frugiperda (Lepidoptera: Noctuidae) and its predator Eriopis connexa (Coleoptera: Coccinellidae). Journal of Environmental Science and Health Part B, 45(6), 557-561.

http://doi.org/10.1080/03601234.2010.493493

Tripathi, S., Shah, K. K., Tiwari, I., \& Shrestha, J. (2020). Farmers' perception about major insect pests of cucurbits and their management. Indonesian Journal of Agricultural Research, 3(3), 153 - 170. https://doi.org/10.32734/injar.v3i3.4414

Turner, C. J., Tempesta, M. S., Taylor, R. B., Zagorski, M. G., Termini, J. C., Schroeder, D. R., \& Nakanishi, K. (1987). An NMR spectroscopic study of azadirachtin and its trimethylether. Tetrahedron, 43, 2789-2803.

Udo, I., \& Ibanga, P. T. (2019). Comparative efficacy of aqueous extract of three botanicals on corn earworm (Heliothis armigera). Asian Journal of Agriculture and Food Scences, 7(1), 15-19 https://doi.org/10.24203/ajafs.v7i1.5411

UNHRC. (2017). Report of the special rapporteur on the right to food A/HRC/34/48.United Nations, 01509 (January), 17-1059. https://reliefweb.int/sites/reliefweb.int/files/resources/1701059.pdf

United Nations Environment Programme Neem: The UN's tree of the 21st century. Nairobi: United Nations Environment Programme; 2012. http://www.unep.org/wed/tree-a-day/neem.asp.

Venkateswarlu, B., Pirat, M., Kishore, N., \& Rasul, A. (2008). Mycorrhizal inoculation in neem (Azadirachta indica) enhances azadirachtin content in seed kernels. World Journal of Microbiology and Biotechnology, 24(7), 1243-1247. http://doi.org/10.1007/s11274-007-9593-2
Verma, V. C., Gond, S. K., Kumar, A., Kharwar, R. N., Boulanger, L. A., \& Strobel, G. A. (2011). Endophytic fungal flora from roots and fruits of an Indian neem plant Azadirachta indica A. Juss., and impact of culture media on their isolation. Indian Journal of Microbiology, 51(4), 469-476. http://doi.org/10.1007/s12088-011-0121-6

Vijayalakshmi, K., Gaur, H. S., \& Gosuremi, B. K. (1985). Neem for the control of plant parasitic nematodes. Neem Newsletter, 2, 35-42.

Weathersbee III, A. A., \& McKenzie, C. L. (2005). Effect of a neem biopesticide on repellency, mortality, oviposition, and development of Diaphorina citri (Homoptera: Psyllidae). Florida Entomologist, 88(4), 401-407. https://doi.org/10.1653/0015

World Health Organisation (1990). Public health impact of pesticides used in agriculture. Geneva: World Health Organisation.

Xuan, T. D., Tsuzuki, E., Hiroyuki, T., Mitsuhiro, M., Khanh, T. D., \& Chung, I. M. (2004). Evaluation on phytotoxicity of neem (Azadirachta indica A. Juss) to crops and weeds. Crop Protection, 23(4), 335-345. http://doi.org/10.1016/i.cropro.2003.09.004

Yadav, I. C., Devi, N. L., Syed, J. H., Cheng, Z., Li, J., Zhang, G., \& Jones, K. C. (2015). Current status of persistent organic pesticides residues in air, water, and soil, and their possible effect on neighboring countries: a comprehensive review of India. Science of the Total Environment, 511, 123-137. http://doi.org/10.1016/i.scitotenv.2014.12.041

Zaki, F. N. (2008). Field application of plant extracts against the aphid, B. brassicae and the whitefly, $B$. $a b a c i$ and their side effects on their predators and parasites. Archives of Phytopathology and Plant Protection, 41(6), 462-466. https://doi.org/10.1080/03235400600881679

Zongo, J. O., Vincent, C., \& Stewart, R. K. (1993). Effects of neem seed kernel extracts on egg and larval survival of the sorghum shoot fly, Atherigona soccata Rondani (Dipt., Muscidae). Journal of Applied Entomology, 115(1-5), 363-369. https://doi.org/10.1111/i.14390418.1993.tb00403.x 